\title{
PREDIKSI KEBERHASILAN IMMUNOTHERAPY PADA PENYAKIT KUTIL DENGAN MENGGUNAKAN ALGORITMA NAÏVE BAYES
}

\author{
Toni Arifin ${ }^{1}$, Siti Syalwah ${ }^{2}$ \\ ${ }^{1}$ Universitas Adhirajasa Reswara Sanjaya \\ e-mail: toni.arifin@ars.ac.id \\ ${ }^{2}$ Universitas Adhirajasa Reswara Sanjaya \\ e-mail: sitisyalwah13@gmail.com
}

\begin{abstract}
Abstrak
Penyakit kutil merupakan masalah kesehatan kulit yang pada umumnya ditandai dengan munculnya benjolan kecil bertekstur kasar pada permukaan kulit yang disebabkan oleh virus yaitu Human Papilloma Virus (HPV). Salah satu teknik pengobatan penyakit kutil adalah Immunotherapy, metode ini merupakan pengobatan dengan meningkatkan sistem kekebalan tubuh untuk mengatasi penyakit kutil. Untuk mengurangi kesalahan deteksi dan menghindari keterlambatan diagnosis penderita penyakit kutil dapat dilakukan penerapan dan pemanfaatan teknik data mining. Salah satu metode data mining yang bisa dimanfaatkan adalah klasifikasi dan metode algoritma yang dapat digunakan untuk klasifikasi adalah algoritma Naive Bayes. Pada penelitian ini, algoritma klasifikasi data mining Naive Bayes diterapkan pada Immunotherapy Data Set. Setelah hasil penelitian diperoleh, terbukti metode data mining menggunakan algoritma Naive Bayes dengan 10-Fold Cross Validation menghasilkan nilai akurasi klasifikasi sebesar $81,11 \%$ dan nilai Area Under ROC (AUC) sebesar 0,63 yang termasuk kategori Good Classification.
\end{abstract}

Kata Kunci: Penyakit Kutil, Immunotherapy, Data Mining, Klasifikasi, Naive Bayes

\begin{abstract}
Warts Disease is a skin health problem that is generally characterized by the appearance of small, rough textured lumps on the skin surface caused by a virus that is Human Papilloma Virus (HPV). One technique of treatment of wart disease is Immunotherapy, this method is a treatment by boosting the immune system to overcome the disease of warts. To reduce detection errors and avoid delays in diagnosing Warts disease, the application of data mining techniques can be applied and used. One method of data mining that can be used is classification and algorithm methods that can be used for classification are the Naive Bayes algorithm. In this study, the Naive Bayes data mining classification algorithm was applied to Immunotherapy Data Set. After the research results were obtained, it has been proven that data mining method using Naive Bayes algorithm with 10-Fold Cross Validation resulted in classification accuracy values of $81,11 \%$ and Area Under ROC (AUC) values of 0.63 which belonged to the Good Classification category.
\end{abstract}

Keywords: Warts Disease, Immunotherapy, Data Mining, Classification, Naive Bayes

\section{Pendahuluan}

Penyakit kutil merupakan salah satu masalah kesehatan kulit yang biasanya ditandai dengan timbulnya benjolan kecil pada permukaan kulit, penyakit ini yang disebab oleh virus yaitu Human Papiloma Virus (HPV). Penularan virus penyebab kutil dapat terjadi dengan mudah, salah satunya hanya bersentuhan langsung dengan seseorang penderita kutil, namun tidak semua orang yang bersentuhan dengan virus Human Papiloma Virus (HPV) akan menimbulkan penyakit kutil. Imunitas tubuh masing-masing orang sangat berpengaruh dalam penularan penyakit ini, penderita yang memiliki imuntas yang bermasalah akan rentan untuk terserang penyakit kutil. Salah satu teknik pengobatan kutil adalah 
dengan Immunotherapy, metode ini merupakan pengobatan dengan meningkatkan sistem kekebalan tubuh untuk mengatasi penyakit kutil. Immunotherapy intralesi adalah pengobatan efektif untuk kutil. Metode ini memiliki respon terapeutik yang lebih baik membutuhkan lebih sedikit sesi, dan mampu mengobati kutil yang sudah lama (Supriyatna \& Mustika, 2018).

Human Papilloma Virus (HPV) adalah virus yang paling sering dijumpai pada penyakit menular seksual dan diduga berperan dalam proses terjadinya kanker. Terdapat sekitar 130 tipe Human Papilloma Virus (HPV) yang telah diindetifikasi (Setiawati, 2014).

Immunotherapy pertama kali diperkenalkan oleh William B Colley. Colley mencatat bahwa beberapa pasien yang mengidap sarcoma ini mengalami regresi pada tumor secara spontan dan ini berkorelasi dengan infeksi bakteri. Colley kemudian menggunakan bakteri untuk menginfeksi pasien kanker dan dalam beberapa kasus, baru-baru ini peran sistem kekebalan tubuh dalam penyakit kanker lebih didefinisikan sebagai Immunoediting

Immunotherapy juga telah dievaluasi dalam gabungan dengan terapi lain seperti pembedahahan, kemoterapi, dan terapi radiasi. Bila digunakan dalam gabungan dengan modalitas sitoreduktif lain ini, maka terapi dinamai sebagai Immunotherapy (Ramadhan \& Mahmudy, 2019).

Immunotherapy adalah salah satu penanganan pada penyakit yang disebabkan oleh virus Human Papilloma Virus (HPV). Metode ini ditemukan pada tahun 1970-an untuk penyembuhan kanker melanoma kan kandung kemih dengan menggunakan agen imun Cytokine namun memiliki efek samping yang besar dan seiring mempelajari respon imun, metode ini terus dikembangkan. Metode Immunotherapy merangsang beberapa sistem kekebalan tubuh manusia dan penggunaan metode ini terbukti ampuh untuk penanganan penyakit yang disebabkan oleh Human Papilloma Virus (HPV) (Ramadhan \& Mahmudy, 2019).

Penelitian terkait digunakan sebagai acuan dan referensi yang dapat memudahkan peneliti dalam menentukan langkah sistematis dari berbagai teori konseptual yang akan dikaji. Penelitian terkait berfungsi untuk menghindari duplikasi dan penanggulangan peneltian atau kesalahan yang sama seperti yang dibuat oleh peneliti sebelumnya (Hermawan, Sukma, \& Halfis, 2019) Berikut penelitian yang juga pernah membahas tentang prediksi keberhasilan Immunotherapy pada penyakit kutil :

Penelitian Hermawan, Sukma, Halfis

Penelitian yang berjudul Analisi Algoritma Klasifikasi C.45 Untuk Memprediksi Keberhasilan Immunotherapy Pada Penyakit Kutil. Dimana dari hasil pengujian menggunakan algoritma naïve bayes dapat memprediksi class untuk semua instance secara tepat dengan nilai akurasi $81,11 \%$.

\section{Metode Penelitian}

Pada penelitian ini diperlukan kerangka penelitian yang akan dilakukan, dibawah ini adalah gambar 1 Kerangka penelitian

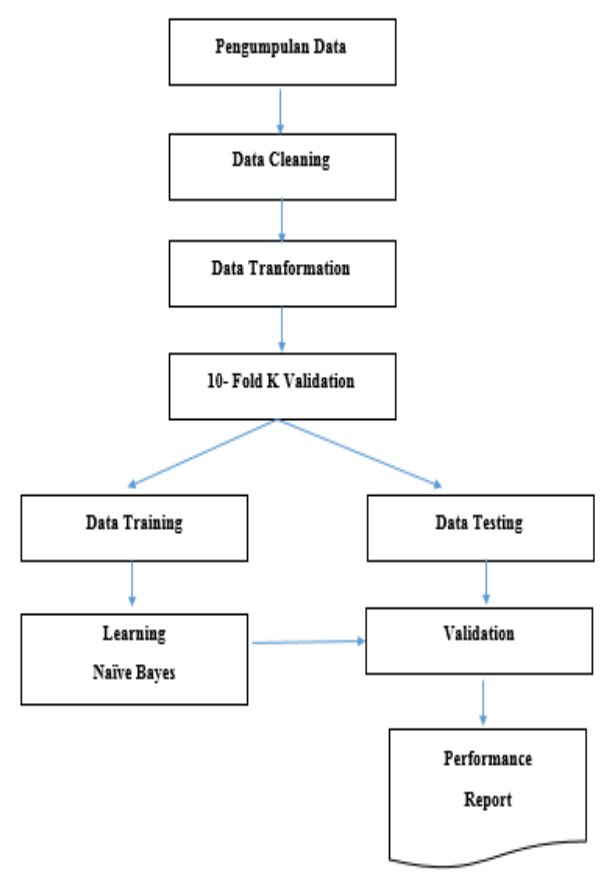

Gambar 1. Kerangka Penelitian

a. Pengumpulan Data

Pada penelitian ini penulis mendapatkan data dari Website University of California Irvine Machine learning Data Repository (UCI Repository) pada tahun 2018. Dataset ini terdiri dari 90 Record dengan 8 atribut.

b. Data Cleanning

Pada Immunotherapy Data Set, penulisan pada class dari diagnosis menggunakan tipe numerikal 1 (Berhasil) dan 0 (Gagal). Algoritma 
Naïve Bayes tidak bisa mengkategorikan dataset dengan class bertipe numerikal. Sehingga dilakukan data cleaning dengan mengubah numerikal 1 menjadi teks Berhasil, dan numerikal 0 menjadi teks Gagal.

c. Data Transformasi

Pada penelitian ini menggunakan Immunotherapy Data Set dengan jumlah 90 record dan 8 atribut. Namun, untuk proses data mining menggunakan algoritma Naive Bayes akan lebih optimal bila semua variabel atau atribut tidak mengandung nilai continuous dan bernilai kategorikal. Sehingga diperlukan proses transformasi data pada tahap pengolahan data awal. Pada immunotherapy Disease Data Set terdiri dari variabel campuran antara variabel diskrit atau kategorikal dan variabel continuous atau numerikal. Proses transformasi yang akan digunakan adalah Discretization. Dalam tahap Discretization, nilai-nilai baku dari atribut numerik (misalnya, age) akan diganti dengan label Interval (10-20, 21-30). Proses ini dilakukan untuk mengubah semua variabel baku atau continuous menjadi variabel dengan nilai interval atau kategorikal.

Di bawah ini adalah tabel yang menjelaskan jumlah data yang dipakai dan nama atribut yang ada pada Immunotherapy Data Set.

Tabel 1. Nama-nama atribut

\begin{tabular}{|c|c|}
\hline No & Atribut \\
\hline 1 & Sex \\
\hline 2 & Age \\
\hline 3 & Time \\
\hline 4 & Number of Warts \\
\hline 5 & Type \\
\hline 6 & Area \\
\hline 7 & Induration Diameter \\
\hline 8 & Result of Treatment \\
\hline
\end{tabular}

Tabel 2. jumlah data 2 kelas dataset

\begin{tabular}{|c|c|}
\hline Kelas Berhasil & 71 \\
\hline Kelas Gagal & 19 \\
\hline Total & $\mathbf{9 0}$ \\
\hline
\end{tabular}

d. Langkah selanjutnya pembagian data set Immunotherapy Dataset menjadi 10 Fold cross validation, semua data set akan dibagi menjadi data training dan data testing

e. Langkah selanjutnya setelah didapatkan atribut terbaik adalah tahapan klasifikasi data dengan metode klasifikasi data mining

f. Setalah data training dan data testing divalidasi dengan menggunakan metode klasifikasi. Langkah terakhir yaitu membandingkan hasil klasifikasi untuk mengetahui metode terbaik untuk klasifikasi dataset Immunotherapy datasert

\section{Naive Bayes Classifier}

Naive Bayes Classifier adalah salah satu algoritma dalam teknik data mining yang menerapkan Bayesian Theorem dalam klasifikasi. Naïve Bayes Classifier merupakan pengklasifikasian statistik yang dapat digunakan untuk memprediksi probabilitas keanggotaan suatu class. Naïve Bayes Classifier terbukti memiliki akurasi dan kecepatan yang tinggi saat diaplikasikan ke dalam database dengan data yang besar lainnya (Herliana, Arifin, Susanti, \& Hikmah, 2018). Persamaan Teorema Bayes (Arifin, 2015)

$$
P(A \mid B)=\frac{P(B \mid A) \cdot P(A)}{P(B)}
$$

Keterangan :

B : Data dengan class yang belum diketahui A : Hipotesis data merupakan suatu class spesifik

$\mathbf{P}(\mathbf{A} \mid \mathbf{B})$ : Probabilitas hipotesis A berdasaran kondisi B (posterior probabilities)

$\mathbf{P}(\mathbf{A})$ : Probabilitas hipotesis A (prior probabilities)

$\mathbf{P}(\mathbf{B} \mid \mathbf{A})$ : Probabilitas B Berdasarkan hipotesis A (Conditional Probabilities)

P(B) : Probabilitas B

Rumus diatas disesuaikan untuk Naive Bayes sebagai berikut:

$$
P(A i \mid B)=\frac{P(B \mid A i) . P(A i)}{P(B)}
$$

$P(B)$ harus dimaksimumkan karena nilainya sama untuk semua kelas, sehingga rumus diatas disederhanakan lagi ke dalam bentuk seperti dibawah ini:

$$
P(A i \mid B)=P(B \mid A i) . P(A i)
$$


Asumsi sederhana dalam Naive Bayes adalah semua atribut kondisinya independen. Jadi tahapan rumusan kelas bagi data tes adalah berdasarkan rumus berikut:

$$
\begin{gathered}
P(B \mid A i)=\prod_{\substack{k=1 \\
\operatorname{Arg} \max _{A i}}}\{(\boldsymbol{P}(B \mid A i) P(A i)\}
\end{gathered}
$$

Sebagai contoh bila ada data baru dan nilai posterior probabilitasnya $P\left(A_{2} \mid B\right)$ memiliki nilai paling besar di antara semua posterior probabilitas $\mathrm{P}\left(\mathrm{A}_{k} \mid \mathrm{B}\right)$ untuk sejumlah $k$ kelas, maka data tersebut termasuk ke dalam kelas $A_{2}$.

\section{Evaluasi dan Validasi}

Validasi adalah proses mengevaluasi akurasi dari sebuah model, validasi mengacu untuk mendapatkan prediksi dengan menggunakan model yang ada kemudian membandingkan hasil yang diperoleh dengan hasil yang diketahui (Gorunescu, 2011). Mengevaluasi akurasi dari model klasifikasi sangat penting, akurasi dari sebuah model mengindikasikan kemampuan model tersebut untuk memprediksi class target (Vercellis, 2009). Untuk mengevaluasi model digunakan metode Confusion Matrix dan Kurva ROC (Receiver Operating Characteristic) (Arifin, 2015)

a. Confusion Matrix

Evaluasi kinerja model klasifikasi didasarkan pada pengujian objek yang diprediksi dengan benar dan salah, hitungan ini ditabulasikan Confusion Matrix (Gorunescu, 2011).Confusion Matrix adalah alat yang berguna untuk menganalisis seberapa baik classifier dapat mengenali tupel dari kelas yang berbeda (Han, Micheline, \& Jian, 2012)

b. Kurva ROC

Kurva ROC banyak digunakan untuk menilai hasil prediksi, kurva ROC adalah teknik untuk memvisualisasikan, mengatur, dan memilih pengklasifikasian berdasarkan kinerja algoritma. Untuk klasifikasi data mining, nilai Area Under ROC (AUC) dapat dibagi menjadi beberapa kelompok (Gorunescu, 2011):

1. $0.90-1.00=$ Excellent Classification

2. $0.80-0.90=$ Good Classification

3. $0.70-0.80=$ Fair Classification

4. $0.60-0.70=$ Poor Classification

5. $0.50-0.60=$ Failure

\section{Hasil dan Pembahasan}

Penerapan algoritma Naive Bayes pada Immunotherapy Data Set dimaksudkan untuk mengetahui dan mendapatkan hasil akurasi lebih baik pada klasifikasi deteksi penyakit Kutil dari penelitian-penelitian sebelumnya. Eksperimen pada algoritma Naive Bayes menggunakan algoritma Naive Bayes dengan menggunakan metode validasi K-Fold Cross Validation.

\section{a. Hasil Eksperimen Naïve Bayes dengan $K$-Fold Cross Validation}

Tabel 3. Hasil Akurasi Model Naive Bayes Menggunakan K-Fold Cross Validation

\begin{tabular}{|c|c|c|}
\hline $\begin{array}{c}\text { Model } \\
\text { (Algoritma } \\
\text { ) }\end{array}$ & $\begin{array}{c}\text { Jumlah Fold } \\
\text { Cross } \\
\text { Validation }\end{array}$ & Akurasi \\
\hline $\begin{array}{l}\text { Naiv } \\
\text { Baye }\end{array}$ & 5 & $80,00 \%$ \\
Saye & 10 & $81,11 \%$ \\
\hline $\begin{array}{l}\text { Naive } \\
\text { Bayes }\end{array}$ & 10 \\
\hline
\end{tabular}

Berikut merupakan hasil evaluasi terdapat pada gambar 2 .

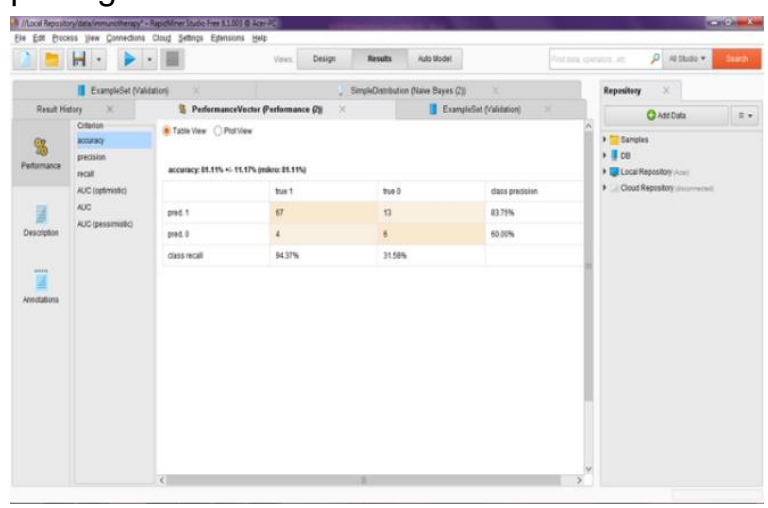

Gambar 2. Hasil Evaluasi Model K-Fold Validation dengan $10 \mathrm{~K}$-fold Validation

Dari confusion matrix pada Gambar IV.1 dapat diukur tingkat akurasi dari klasifikasi sebagai berikut:

$\mathrm{TP}=67 ; \mathrm{FP}=4 ; \mathrm{TN}=6 ; \mathrm{FN}=13$

Akurasi $=((\mathrm{TP}+\mathrm{TN}) /(\mathrm{TP}+\mathrm{TN}+\mathrm{FP}+\mathrm{FN})) * 100$

Akurasi $=((67+6) /(67+6+4+13)) * 100$

Akurasi $=81,11 \%$ 


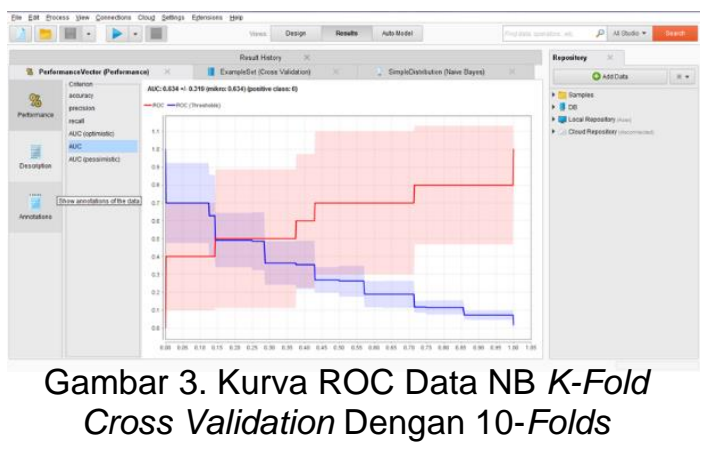

Pada tabel 3.1 hasil akurasi yang diperoleh dengan penerapan metode Naive Bayes menggunakan teknik evaluasi $K$-Fold Cross Validation untuk klasifikasi dalam memprediksi keberhasilan Immunotherapy Data Set telah meningkat. Metode evaluasi 10-Fold Cross Validation terbukti memberikan hasil akurasi lebih baik dengan nilai akurasi $81,11 \%$ dibandingkan metode evaluasi 5-Fold Cross Validation dengan nilai akurasi $80.00 \%$. Hasil yang diperoleh dari pengolahan kurva ROC seperti yang terlihat di Gambar 3.2 menghasilkan nilai AUC sebesar 0,63 yang termasuk kategori good Classification

\section{b. Perbandingan Hasil Penelitian Dengan Penelitian Sebelumnya}

Perbandingan hasil pada penelitian ini dengan penelitian-penelitian sebelumnya adalah untuk mengevaluasi hasil

keseluruhan pada penelitian ini. Penelitian ini adalah penelitian lanjutan dari penelitian- penelitian sebelumnya dengan objek data yang sama, yaitu Immunotherapy Data Set. Penelitian yang dilakukan oleh penelitian sebelumnya, dengan judul Analisis Algoritma Klasifikasi C.45 untuk Memprediksi Keberhasilan Immunotherapy Pada Penyakit Kutil dengan hasil akurasi sebesar $74,07 \%$. dan penelitian selanjutnya dengan judul Penerapan Algoritma Naïve Bayes Untuk Mengukur Nilai Akurasi Klasifikasi Diagnosis Cryotherapy Pada Penyakit Kutil dengan hasil akurasi adalah $91,67 \%$.

Tabel 4. Perbandingan Hasil Penelitian

\begin{tabular}{|c|l|c|c|}
\hline $\begin{array}{c}\mathbf{N} \\
\mathbf{0}\end{array}$ & $\begin{array}{c}\text { Judul } \\
\text { Penelitian }\end{array}$ & Algoritma & Akurasi \\
\hline 1. & Analisis & Algoritma & \\
& Algoritma & C.45 & \\
& Klasifikasi & & \\
& C.45 untuk & & \\
& Mempredik & & \\
\hline
\end{tabular}

\begin{tabular}{|l|l|l|l|}
\hline & Si & & \\
Keberhasil & & & \\
an & & \\
Immunoth & & \\
erapy & & \\
pada & & \\
penyakit & & \\
& kutil & & \\
\hline 2. & Prediksi & Algoritma & 81,11\% \\
& Keberhasil & Naïve & \\
an & Bayes & \\
Immunoth & end & \\
erapy & & \\
Pada & & \\
penyakit & & \\
kutil & & \\
dengan & & \\
Mengguna & & \\
kan & & \\
Algoritma & & \\
Naïve & \\
Bayes & & \\
\hline
\end{tabular}

Pada Tabel 3.2 adalah perbandingan hasil penelitian pada objek Immunotherapy Data Set dari seluruh penelitian yang telah dilakukan. Dari tabel tersebut terbukti bahwa Naive Bayes dengan teknik 10-Fold Cross Validation berhasil meningkatkan hasil akurasi pada klasifikasi deteksi Penyakit Kutil menjadi nilai akurasi terbaik dengan $81,11 \%$ dan $\mathrm{ROC}$ sebesar 0.63 .

\section{Kesimpulan}

Pada penelitian ini dilakukan eksperimen terhadap algoritma Naive Bayes untuk mengklasifikasi Immunotherapy Data Set. Untuk mencari hasil optimal dari klasifikasi, dilakukan metode dalam validasi performa klasifikasi. metode K-Fold Cross Validation. Kesimpulan yang didapat dari hasil penelitian ini adalah:

a. Telah diterapkan algoritma klasifikasi Naive Bayes pada Immunotherapy Data Set menggunakan metode $k$-fold validasi performa klasifikasi.

b. Telah diketahui hasil akurasi dari algoritma Naive Bayes untuk klasifikasi Immunotherapy Data Set dengan hasil akurasi optimal sebesar $81,11 \%$ menggunakan 10-Fold Cross Validation.

\section{Saran-Saran}

Penelitian ini hanya terbatas pada eksperimen algoritma Naive Bayes dan analisa terhadap hasil eksperimen tersebut, 
dan tidak mengimplementasikan algoritma tersebut menjadi sebuah aplikasi.

a. Pada penelitian berikutnya bisa dilakukan eksperimen menggunakan algoritma Naive Bayes menggunakan dataset lain untuk mengetahui performa Naive Bayes Classifier untuk dataset dengan jumlah data yang lebih beragam.

b. Pada penelitian berikutnya bisa dilakukan eksperimen menggunakan Immunotherapy Data Set menggunakan metode algoritma data mining yang lain yang belum digunakan untuk dataset ini untuk mengetahui performa algoritma lainnya dalam mengklasifikasi penyakit kutil.

c. Tingkat akurasi algoritma tersebut mencapaui $81,11 \%$. Dimana artinya pengujian data keberhasilan Immunotherapy dengan menggunakan algoritma Naïve bayes 10 k-fold validation menghasilkan akurasi yang cukup baik dibandingkan penelitian sebelumnya yang dilakukan dengan data yang sama. Untuk penelitian berikutnya diperlukan penelitian lebih lanjut mengenai atribut yang mempengaruhi pengolahan data serta menggunakan lebih banyak data guna meningkatkan kualitas hasil penelitian.

\section{Referensi}

Arifin, T. (2015). Metode Data Mining Untuk Klasifikasi Data Sel Nukleus Dan Sel Radang Berdasarkan Analisa Tekstur. Informatika, II(2), 425-433.

Gorunescu, F. (2011). Data mining: Concepts, models and techniques. Retrieved from https://doi.org/10.1007/978-3-64219721-5

Han, J., Micheline, K., \& Jian, P. (2012). DATA MINING (Concept and Techniques). Retrieved from https://doi.org/10.1017/CBO97811074 15324.004.

Herliana, A., Arifin, T., Susanti, S., \& Hikmah, A. B. (2018). Feature Selection of Diabetic Retinopathy Disease Using Particle Swarm Optimization and Neural Network. 2018 6th International Conference on Cyber and IT Service Management (CITSM), (Citsm), 1-4. https://doi.org/10.1109/CITSM.2018.8 674295

Hermawan, A., Sukma, A. R., \& Halfis, R. (2019). Analisis Algoritma Klasifikasi C
4. 5 Untuk Memprediksi Keberhasilan Immunotherapy Pada Penyakit Kutil. $V(2)$, 155-160. https://doi.org/10.31294/jtk.v4i2

Ramadhan, R., \& Mahmudy, W. F. (2019). Optimasi Bobot Awal Extreme Learning Machine menggunakan Algoritme Genetika untuk Klasifikasi Penanganan Human Papilloma Virus. 3(6), 5616-5623.

Setiawati, D. (2014). Human Papilloma Virus Dan Kanker Serviks. 450-459.

Supriyatna, A., \& Mustika, W. P. (2018). Komparasi Algoritma Naive bayes dan SVM Untuk Memprediksi Keberhasilan Imunoterapi Pada Penyakit Kutil. (2), 152-161. 